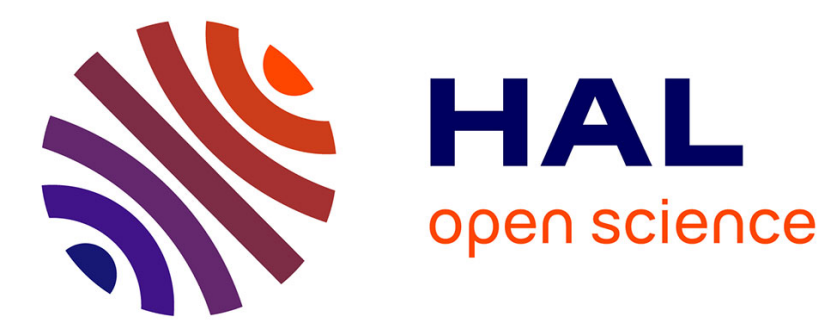

\title{
Treatment of primary mediastinal large B cell lymphoma with an alternating chemotherapy regimen based on high-dose methotrexate
}

\author{
T. Fietz, W. U. Knauf, M. Hänel, A. Franke, M. Freund, E. Thiel
}

\section{- To cite this version:}

T. Fietz, W. U. Knauf, M. Hänel, A. Franke, M. Freund, et al.. Treatment of primary mediastinal large B cell lymphoma with an alternating chemotherapy regimen based on high-dose methotrexate. Annals of Hematology, 2008, 88 (5), pp.433-439. 10.1007/s00277-008-0625-2 . hal-00477987

\section{HAL Id: hal-00477987 \\ https://hal.science/hal-00477987}

Submitted on 30 Apr 2010

HAL is a multi-disciplinary open access archive for the deposit and dissemination of scientific research documents, whether they are published or not. The documents may come from teaching and research institutions in France or abroad, or from public or private research centers.
L'archive ouverte pluridisciplinaire HAL, est destinée au dépôt et à la diffusion de documents scientifiques de niveau recherche, publiés ou non, émanant des établissements d'enseignement et de recherche français ou étrangers, des laboratoires publics ou privés. 


\title{
Treatment of primary mediastinal large B cell lymphoma with an alternating chemotherapy regimen based on high-dose methotrexate
}

\author{
T. Fietz • W. U. Knauf • M. Hänel • A. Franke • \\ M. Freund $\cdot$ E. Thiel • \\ for the East German Study Group on Hematology and \\ Oncology-OSHO
}

Received: 28 April 2007 / Accepted: 21 December 2007 / Published online: 14 October 2008

(C) Springer-Verlag 2008

\begin{abstract}
Primary mediastinal large B cell lymphomas (MLCL) differ from other diffuse large cell lymphomas, leading to a description as a separate entity in the current World Health Organization classification. Dose intensification improves long-term results, but no standard therapy has been established so far. We investigated the use of a high-dose methotrexate-based alternating chemotherapy regimen (BALL protocol of the German ALL study group) followed by consolidative mediastinal radiotherapy first as a single-center trial, then later as a prospective multicenter trial in 44 patients with a median age of 33 years. Response rates exceeded $90 \%$ with an overall survival rate of $80 \%$ in the single-center group (8.6 years median follow-up) and $82 \%$ in the multicenter group (2.5 years follow-up).Short-term toxicity was manage-
\end{abstract}

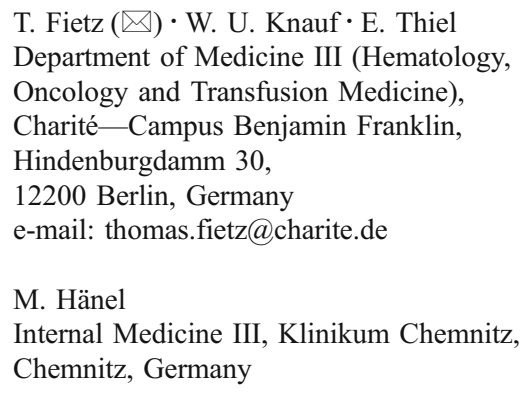

M. Hänel

Internal Medicine III, Klinikum Chemnitz,

Chemnitz, Germany

\section{A. Franke}

Hematology and Oncology, University of Magdeburg,

Magdeburg, Germany

\section{Freund}

Hematology and Oncology, University of Rostock,

Rostock, Germany

Present address:

W. U. Knauf

Oncology Bethanien,

Frankfurt am Main, Germany able, but required hospitalization: the rates of grade 3 or 4 toxicity were $20 \%$ (for mucositis), $42 \%$ (for neutropenia), $29 \%$ (for thrombocytopenia), and 9\% (for neutropenic fever). No relapse occurred more than 2 years after diagnosis and initiation of treatment, but unfortunately, no patient with overt progression or relapse within these 2 years could be salvaged. Future directions in the treatment of MLCL will not focus on further dose intensification, but rather on the incorporation of (radio)immunotherapy as a therapeutic tool and gene expression profiling as well as positron emission tomographycomputed tomography as stratifying tools.

Keywords Primary mediastinal large B cell lymphoma . High-dose methotrexate · Long-term results .

Prospective multicenter study

\section{Introduction}

Primary mediastinal large B cell lymphomas (MLCL) differ from other diffuse large cell lymphomas: they convey a unique gene expression profile reminiscent of Hodgkin's disease $[1,2]$, are characterized by an occlusive infiltration pattern (e.g., with vena cava superior syndrome due to the concomitant sclerosis), and typically affect younger patients. The histopathological reproducibility of MLCL has been the hallmark of its characterization as a distinct disease entity in the current World Health Organization classification of lymphoma [3]. However, a distinction based on histopathological features alone can be difficult and additional markers are currently included into routine diagnosis [4]. Newer, gene array-based grouping of aggressive non-Hodgkin's lymphoma support the unique position with MLCL representing a defined subtype besides 
germinal center B cell-like (GCB) and activated B cell-like (ABC) diffuse large cell lymphoma [1, 2, 5].

The results of a cyclophosphamide, hydroxydaunorubicin (adriamycin), oncovin (vincristine), prednisone/prednisolone (CHOP)-based chemotherapy in European and non-European countries have been disappointing [6-8], making the treatment of this particular entity unique among the diffuse large B cell lymphomas (DLCL) irrespective of the individual (partially later developed) prognostic score. Dose intensification has always played a major role in the treatment of the disease and, in the prerituximab era, clearly improved the results of CHOP-based chemotherapy regimen [8, 9-13]. An international standard therapy, however, has not been established so far. Furthermore, a differentiation of the residual tumor mass after chemotherapy (scar tissue vs. vital tumor cells) can sometimes be very challenging and often radiation or high-dose therapy as consolidation treatment are added to the initial therapy protocol. This has individualized treatment of patients with MLCL and hampered comparison of the results of different approaches to the disease.

In this study, we report the results of a high-dose methotrexate-based alternating chemotherapy regimen (BALL protocol of the German Multicenter ALL Study Group [GMALL]), which has proven very effective in the treatment of mature B-ALL, a disease that biologically represents a leukemic B-NHL [14]. Since 1988, we investigated this regimen also in MLCL-first, as a single-center trial, then later as a multicenter trial. Longterm results on remission and toxicity in both cohorts with a maximum follow-up of 16 years are presented.

\section{Design and methods}

Between June 1988 and May 2004, 44 patients were included into this prospective, nonrandomized trial: 15 patients in a single-center pilot protocol (Charité group) and 29 patients in a subsequent multicenter trial coordinated by the East German Study Group on Hematology and Oncology (OSHO study \#49). Altogether, eight centers participated and included between one and eight patients into the OSHO \#49 trial. Inclusion criteria were histologically confirmed diagnosis of MLCL, age 16-75 years, and no prior chemotherapy or radiotherapy excluding patients with severe, uncontrolled comorbidities. Primary end points were remission rate and toxicity, secondary end points were duration of remission and overall survival (OS). Toxicity grading followed the common toxicity criteria (CTC) version 2.0. The local histopathological diagnosis had to be confirmed by a member of the National Lymphoma Reference Panel. The study was approved by the local ethics committee and by the ethics committees of participating centers.
Patient characteristics

All patients were previously untreated, the patient characteristics are summarized in Table 1. Two of the first patients in the late 1980s within our single-center pilot phase underwent surgery (one as a primary approach in an external hospital, one after chemotherapy with extirpation of necrotic tissue without vital tumor cells).

Of the 29 patients registered into the OSHO study, 28 patients were evaluable (one patient with initial report lacking follow-up). Two patients died due to sepsis during the first cycle. For the OSHO protocol, an additional systematic evaluation of toxicity according to the CTC criteria was performed.

\section{Treatment protocol}

All patients were treated according to the B-ALL protocol of the GMALL based on high-dose methotrexate consisting of six chemotherapy cycles: three times block A [day 1, $1,500 \mathrm{mg}$ methotrexate $/ \mathrm{m}^{2}$ for $24 \mathrm{~h}$; days $1-5$, ifosfamide $800 \mathrm{mg} / \mathrm{m}^{2}$; days $4-5, \mathrm{VM}-26100 \mathrm{mg} / \mathrm{m}^{2}$ and ara-C $2 \times$ $150 \mathrm{mg} / \mathrm{m}^{2}$ (bid); days $1-5$, dexamethasone $10 \mathrm{mg} / \mathrm{m}^{2}$ p.o.] and three times block B [day 1, vincristine $2 \mathrm{mg}$ i.v., MTX as in block A; days $1-5$, cyclophosphamide $200 \mathrm{mg} / \mathrm{m}^{2}$; days $4-5$, adriamycin $25 \mathrm{mg} / \mathrm{m}^{2}$; days $1-5$, dexamethasone $10 \mathrm{mg} / \mathrm{m}^{2}$ p.o.] applied alternatively every 3 weeks (block A1, B1, A2, B2, A3, B3). Ten percent of the methotrexate dose was given as a 30 -min bolus, $90 \%$ as a 23.5 -h infusion. After $42 \mathrm{~h}$, a rescue with folinic acid was initiated and intensified, if methotrexate levels remained elevated. All patients were scheduled for consolidative involved-field radiation to the initial mediastinal mass after completion of chemotherapy with $32 \mathrm{~Gy}$. In case of progression or $<75 \%$ reduction in tumor size after four cycles of chemotherapy, patients were switched to alternative therapy protocols including hematopoietic cell transplantation. In case of a residual mediastinal mass with suspected lymphoma activity (e.g., positive gallium or positron emission tomography scan) after chemotherapy and radiation, a subsequent high-

Table 1 Patient characteristics

\begin{tabular}{lll}
\hline & $\begin{array}{l}\text { Monocentric } \\
\text { (Charité) }\end{array}$ & $\begin{array}{l}\text { OSHO } \\
\text { study \#49 }\end{array}$ \\
\hline Patients (F/M) & $15(10 / 5)$ & $29(14 / 15)$ \\
Median age (years, range) & $33(18-62)$ & $33(19-74)$ \\
LDH at presentation & $363(130-1,570)$ & $624(55-1,479)$ \\
$\quad($ median in $\mu$ mol/L, range) & & 56 \\
Pleural effusion (\%) & 27 & 50 \\
Pericardial effusion (\%) & 40 & 39 \\
B-symptoms $(\%)$ & 40 & 14 \\
Ann Arbor stage $>2(\%)$ & 20 & \\
\hline
\end{tabular}


dose chemotherapy with autologous progenitor cell support was performed in the Charite group (three patients).

Response criteria and statistical analysis

Tumor response was evaluated according to standard criteria with $>25 \%$ enlargement in the product of two perpendicular parameters defined as progressive disease, $<50 \%$ lymphoma mass reduction defined as no response, $>50 \%$ reduction defined as partial response, no evidence of assessable lymphoma being a complete remission, and complete remission with residual fibrotic mediastinal remnants and no systemic manifestation being classified as CRr.

Survival was calculated from the beginning of chemotherapy. Confidence intervals were computed by the modified Wald method [15]. The statistical analysis in the multicenter protocol followed the two-step minimax design by Simon [16] with a $p_{0}$ of $50 \%$ and a $p_{1}$ of $70 \%$. Assuming an alpha error of $5 \%$ and a beta error of $20 \%$, altogether 37 evaluable patients were calculated. An early stopping threshold was set with a minimum of 13 out of 23 patients achieving a remission. With the advent of rituximab, the study was halted because of slow accrual after 29 patients in the multicenter arm. It was decided not to retrospectively pool both patient cohorts to allow a statistical analysis as originally designed but rather to present the results as separate Kaplan-Meier plots for the older monocentric as well as the later multicenter arm.

\section{Results}

\section{Response to chemotherapy}

During the first cycle of chemotherapy, two multicenter patients died following septic complications within the chemotherapy-induced nadir. Both patients were at higher risk of complications either because of age (75 years) or reduced Karnofski index (80\%) prior to chemotherapy. Following intestinal mucositis with its disrupted gastrointestinal barrier, Escherichia coli and Enterobacter cloacae could be isolated from blood cultures.

The remission achieved after four cycles of therapy was rarely complete; an additional two cycles, however, increased the rate of $\mathrm{CR}$ and $\mathrm{CRr}$ from $11 \%$ (OSHO group) to $63 \%$ (both groups together, best response of all evaluable patients, 95\% confidence interval $0.48-0.76$ ). The rate of partial remissions was $30 \%$ (both groups), adding up to an overall response rate of $93 \%$ ( 40 of 43 evaluable patients, 95\% confidence interval $0.81-0.98$ ) including the two patients with early death following infectious complications (Table 2).
Table 2 Response to chemotherapy

\begin{tabular}{lll}
\hline & $\begin{array}{l}\text { Monocentric } \\
\text { (Charité) }\end{array}$ & $\begin{array}{l}\text { OSHO } \\
\text { sstudy \#49 }\end{array}$ \\
\hline PR after four cycles & n.d. & $75 \%(21 / 28)$ \\
CR/CRr after four cycles & n.d. & $11 \%(3 / 28)$ \\
PR after six cycles & $27 \%(4 / 15)$ & $32 \%(9 / 28)$ \\
CR/CRr after six cycles & $73 \%(11 / 15)$ & $57 \%(16 / 28)$ \\
Median follow-up & $3,152+$ & $904+$ \\
$\quad$ (days, censored) (years) & $(165-5,970)(8.6)$ & $(186-1,728)(2.5)$ \\
\hline
\end{tabular}

The maximal response after four and six cycles of chemotherapy is shown

Within the pilot trial, four patients experienced an early progression within 3 months after the completion of six cycles of therapy: unfortunately, one patient was lost to follow-up after rescue therapy, extirpation, and radiation. The three other patients received high-dose chemotherapy with autologous stem cell support as rescue therapy, in one case followed by a haploidentical allogeneic stem cell transplantation (SCT). However, they all died with progressive disease (Figs. 1, 2, 3, and 4).

In the OSHO study group, all patients with complete remission remained in continuous remission during followup. Of the seven patients withdrawn from the trial because of suboptimal response $(<75 \%$ tumor reduction after four cycles for five patients, progressive disease after two cycles for two patients leading to a $68 \%$ freedom from treatment failure $[\mathrm{FFTF}]$ rate as defined per protocol, including the two patients with lethal infectious complications; $95 \%$ confidence interval 0.49-0.82; Fig. 1), three patients could be rescued with high-dose chemotherapy. However, no patient who was clearly progressive in tumor diameter at any time point during therapy survived overt relapse/ progression for more than 1 year even following allogeneic rescue transplantation in one case.

The progression-free survival rate (PFS) was 73\% (11/ $15,95 \%$ confidence interval $0.47-0.9)$ for the Charité group where no lethal complications were observed and $85 \%$ (22/ $26,95 \%$ confidence interval $0.66-0.94$ ) for the OSHO study group (excluding two patients with lethal septic complications during cycle 1; Fig. 2).

Looking at OS, $80 \%$ of patients within the pilot trial (12/ $15,95 \%$ confidence interval $0.54-0.94)$ and $82 \%(23 / 28$, $95 \%$ confidence interval $0.64-0.93$ ) within the OSHO multicenter study are alive with no evidence of disease at a median follow-up of 8.6 and 2.5 years, respectively (Fig. 3).

There was no correlation between lactate dehydrogenase (LDH; $66 \%$ of patients presented with an elevated LDH), pericardial or pleural effusion, and response to chemotherapy or probability of relapse. Of note, all relapses occurred during the first 2 years after diagnosis. 


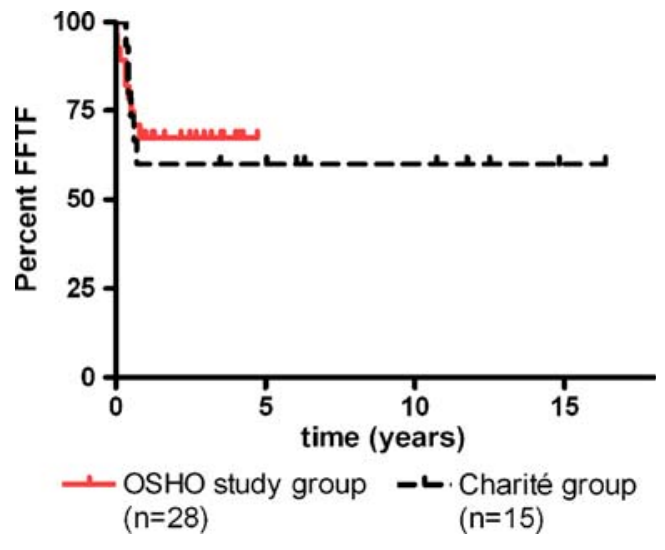

Fig. 1 FFTF according to Kaplan-Meier in patients with primary MLCL treated with a high-dose methotrexate-based chemotherapy

Short-term toxicity

As expected for a high-dose methotrexate-containing regimen, mucositis represents a major hurdle of this chemotherapy approach: $20 \%$ of all patients developed a grade 3 or 4 mucositis per cycle usually requiring intravenous morphine. The rate of grades 3 and 4 hematologic toxicities, however, were surprisingly tolerable and lower as expected for this intensive regimen. Alsoinstead of a mucositis allowing penetration of gastrointestinal bacterial colonizers into the blood system-neutropenic fever was not a major problem $(<10 \%$ risk per cycle). Although overall toxicity was well manageable, clearly, this regimen shows substantial short-term toxicity and requires inpatient service. The results are summarized in Table 3.

\section{Long-term toxicity}

Long-term toxicity was acceptable. In our single-center cohort with a mean follow-up of 9.4 years (3,440 days), we observed one case of hepatitis $\mathrm{C}$ (an association to red

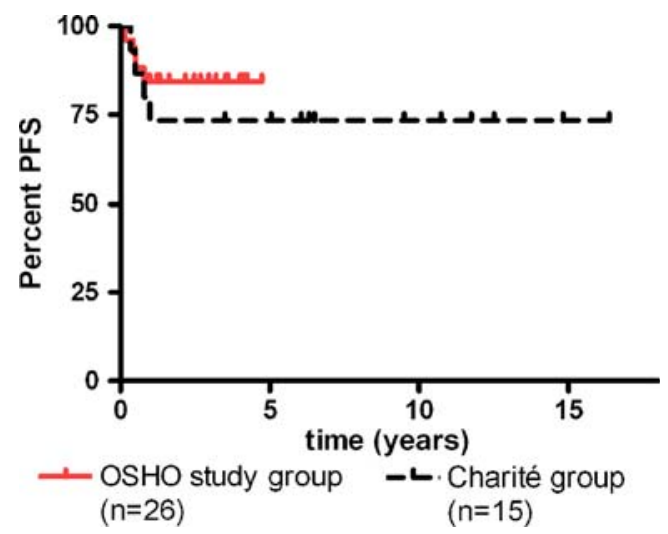

Fig. 2 PFS according to Kaplan-Meier in patients with primary MLCL treated with a high-dose methotrexate-based chemotherapy

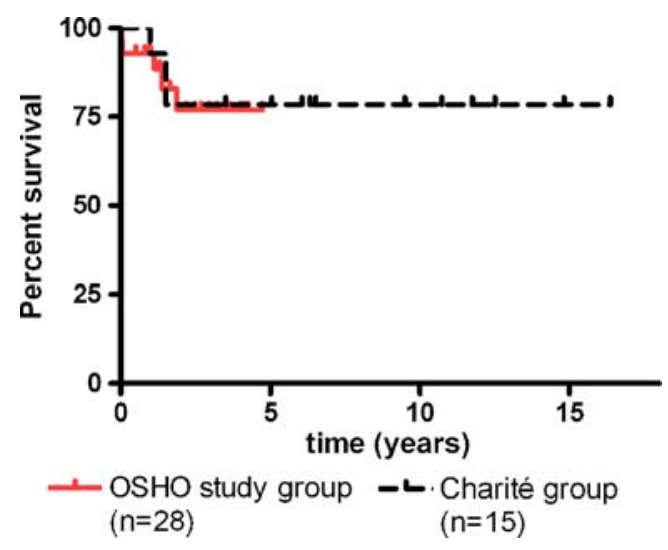

Fig. 3 OS according to Kaplan-Meier in patients with primary MLCL treated with a high-dose methotrexate-based chemotherapy

blood cell transfusion could not be proven, but hepatitis screening before chemotherapy initiation was not performed in this case). There were no secondary malignancies including therapy-associated leukemia. One patient shows persistent reduced neutrophil counts (absolute neutrophil count $1.3 / \mathrm{nL}$ ) 3 years after therapy. A thorough work-up including bone marrow cytology, bone marrow biopsy, and flow cytometry could not prove the suspected myelodysplastic syndrome.

One female patient developed a rhinocerebral mucor mycosis and needs to be on continuous therapy with itraconazole. The biopsy-proven mucor has been stable for 5 years now. Another patient developed an osteonecrosis of the femoral head. Generally, there were no complaints concerning reduced mental or physical fitness $>2$ years after completion of treatment. Interestingly, three patients became pregnant after chemotherapy and radiotherapy and gave birth to three healthy children (one patient had a twin pregnancy and one patient lost one child).

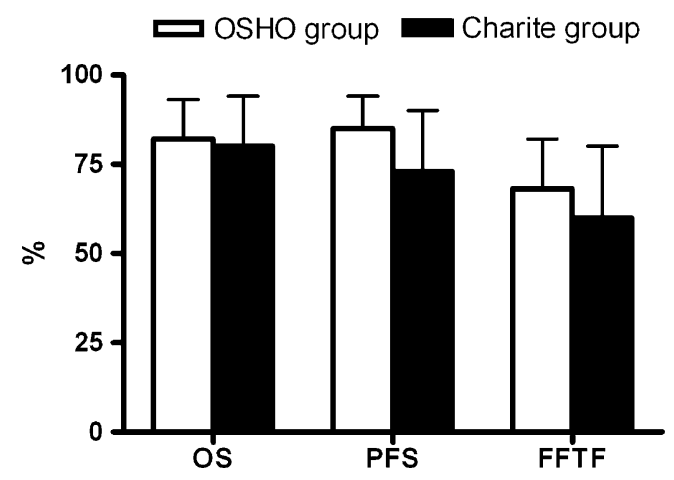

Fig. 4 OS, PFS, and FFTF with 95\% confidence intervals (error bars) in patients with primary MLCL treated with a high-dose methotrexate-based chemotherapy (see text) 
Table 3 Toxicity in 142 cumulative cycles of chemotherapy in the OSHO study \#49 group (according to CTC version 2.0)

\begin{tabular}{lcc}
\hline & CTC $3^{\circ}$ toxicity (\%) & CTC $4^{\circ}$ toxicity (\%) \\
\hline Mucositis & 9 & 11 \\
Fever & 8 & 1 \\
Neutropenia & 22 & 20 \\
Thrombocytopenia & 16 & 13 \\
Anemia & 12 & 2 \\
Nausea/emesis & 2 & 0 \\
Renal & 2 & 3 \\
Hepatic & 2 & 0 \\
\hline
\end{tabular}

\section{Discussion}

Since its first definite description as a distinct entity based on a combination of histopathological features and a typical clinical presentation in the early 1980 s $[17,18$, reviewed in 19], patients suffering from primary MLCL have undergone various chemotherapy-based approaches to achieve cure of the disease.

Based on the disappointing results with CHOP-like therapy [6-8], we started exploring dose intensification with a methotrexate-based alternating chemotherapy regimen in the late 1980s. Simultaneously, this regimen was also investigated in the treatment of another aggressive $\mathrm{B}$ cell disorder, namely, Burkitt's lymphoma/mature B-ALL. Because of the impressive improvement in OS achieved with this alternating regimen, it has meanwhile become standard therapy for Burkitt's lymphoma/mature B-ALL in Germany [14]. We now report our single-center long-term results in 15 patients suffering from MLCL. This data could be reproduced in a larger multicenter, prospective study performed by the East German Study Group on Hematology and Oncology (OSHO) including 29 patients, also reported in this study.

The applied high-dose methotrexate-based alternating chemotherapy regimen led to excellent response rates $(>90 \%)$ in our patient cohort with MLCL. Relapse occurred only within the first 2 years after therapy, but most often during or shortly after chemotherapy following a partial remission. Once patients have crossed the 2-year border after diagnosis, remissions are reliable and lasting; as a matter of fact (and in contrary to diffuse large cell lymphoma), we did not see a single relapse beyond the 2 -year border. This has also been observed by other groups [20] supporting the hypothesis of the different natural histories of MLCL and DLCL.

Once overt relapse occurred, the course of the disease in our cohort was fatal irrespective of the type of salvage treatment applied including high-dose chemotherapy and allogeneic SCT. Up to now, only one case report with a successful rescue therapy has been published [21]. Therefore, intensified adjuvant (i.e., high-dose chemotherapy) and/or local consolidative (i.e., radiotherapy) approaches, especially in patients with a residual tumor mass, seem justified and, as a matter of fact, are favored by most centers. In patients with a suboptimal response, defined as $<75 \%$ reduction in tumor diameter after four chemotherapy cycles, high-dose chemotherapy with autologous stem cell rescue is a feasible and advisable approach. However, as could be expected in a lymphoma with often extensive sclerotic proliferation, remissions tend to occur protracted in the course of chemotherapy compared to other aggressive lymphomas. A residual mass at the site of the often bulky primary disease manifestation is common, and some of our patients undergoing high-dose chemotherapy because of insufficient tumor mass reduction might have been overtreated.

Clearly, this underscores the emerging role of a PETcomputed tomography (CT) allowing not only to identify residual vital tumor, but also allowing to stratify according to tumor response in the course of the disease. The advantage of a gallium scan to judge the dignity of a residual mass has been reported several years ago [22]. Another helpful new tool will be gene expression profiling. First results provide evidence that aggressive MLCL not responding to chemotherapy actually differs from the ordinary MLCL genetic pattern and might rather be (re) classified as ABC-type DLCL [1].

A change in current MLCL treatment is the integration of immunotherapy, either the unconjugated anti-CD20 antibody rituximab or the radioimmunoconjugates ibritumomab tiuxetan or tositumomab, which are under investigation in various trials. Surprisingly, first results with rituximab added to standard CHOP showed inferior survival compared to methotrexate-containing regimen [20] or no benefit in methotrexate-containing regimen for the addition of rituximab [23]. The addition of rituximab to a nonmethotrexate regimen, however, seems to improve results $[24,25]$.

Our results prove manageable short-term toxicity with an acceptable rate of long-term complications. The observed restoration of gonadal function in young patients undergoing intensive chemotherapy including autologous SCT especially when omitting total body irradiation has been described [26]. Of note, our cohort does not support the often cited predilection of MLCL in females [27]. Also, we could not correlate factors like age, LDH, pleural, or pericardial effusion to survival or response, making standard prognostic scores like the International Prognostic Index not reliable for risk stratification in this disease entity - this is supported by the results of other groups $[13,20]$.

The OS in our prospective study $(80 \%$ with a follow-up of 8.6 years in the single-center group, $82 \%$ with a followup of 2.5 years in the multicenter group) compares favorably to the results reported in a larger retrospective analysis with another chemotherapy approach including methotrexate, namely, MACOP-B (71\% projected 10 -year 
survival with a median follow-up of 4.5 years [10]). This might be due to the increased methotrexate dose in our protocol. As a drawback, especially the methotrexate is responsible for a substantial part of the toxicity and requires inpatient service.

One argument in favor of high-dose methotrexate is its ability to penetrate the blood-brain barrier. Although with rituximab we see an increased OS at least in aggressive B-NHL [28, 29], the number of central nervous system (CNS) relapses remains unchanged due to the inadequate diffusion of rituximab into the liquor [30]. Considering a per se increased CNS relapse risk in MLCL compared to other lymphoma [31], this might count as an additional argument for the integration of i.v. methotrexate in the therapy for MLCL; furthermore, probably sparing the need for an additional intrathecal therapy. With most of the CNS relapses in MLCL occurring in the CNS parenchyma, the value of an intrathecal therapy is discussed controversially, anyway [31, 32]. At least in our cohort of high-risk patients, we did not observe any CNS relapse.

In summary, the successful application of a methotrexatebased alternating chemotherapy regimen in mature B-ALL accomplished sustained remissions in the majority of patients suffering from MLCL. The toxicity profile is dominated by mucositis, hematotoxicity, and neutropenic fever requiring hospitalization. Long-term toxicity with a follow-up of maximum 16 years, however, is acceptable as indicated by three uncomplicated pregnancies after treatment. The course for cure is set when remissions last more than 2 years. Patients with overt progression or relapse within the first 2 years in our series could not be salvaged. The integration of gene expression profiling, PET-CT, and immunotherapy into new therapy protocols will help us to further improve therapy results.

\section{References}

1. Rosenwald A, Wright G, Leroy K, Yu X, Gaulard P, Gascoyne RD, Chan WC, Zhao T, Haioun C, Greiner TC, Weisenburger DD, Lynch JC, Vose J, Armitage JO, Smeland EB, Kvaloy S, Holte H, Delabie J, Campo E, Montserrat E, Lopez-Guillermo A, Ott G, Muller-Hermelink HK, Connors JM, Braziel R, Grogan TM, Fisher RI, Miller TP, LeBlanc M, Chiorazzi M, Zhao H, Yang L, Powell J, Wilson WH, Jaffe ES, Simon R, Klausner RD, Staudt LM (2003) Molecular diagnosis of primary mediastinal B cell lymphoma identifies a clinically favorable subgroup of diffuse large B cell lymphoma related to Hodgkin lymphoma. J Exp Med 198(6):851-862

2. Savage KJ, Monti S, Kutok JL, Cattoretti G, Neuberg D, De Leval L, Kurtin P, Dal Cin P, Ladd C, Feuerhake F, Aguiar RC, Li S, Salles G, Berger F, Jing W, Pinkus GS, Habermann T, Dalla-Favera R, Harris NL, Aster JC, Golub TR, Shipp MA (2003) The molecular signature of mediastinal large B-cell lymphoma differs from that of other diffuse large B-cell lymphomas and shares features with classical Hodgkin lymphoma. Blood 102(12):3871-3879
3. Jaffe ES (2001) WHO classification of tumours, pathology and genetics, tumours of haematopoietic and lymphoid tissues. IARC, Lyon, France

4. Rodig SJ, Savage KJ, LaCasce AS, Weng AP, Harris NL, Shipp MA, Hsi ED, Gascoyne RD, Kutok JL (2007) Expression of TRAF1 and nuclear c-Rel distinguishes primary mediastinal large cell lymphoma from other types of diffuse large B-cell lymphoma. Am J Surg Pathol 31(1):106-112

5. Bea S, Zettl A, Wright G, Salaverria I, Jehn P, Moreno V, Burek C, Ott G, Puig X, Yang L, Lopez-Guillermo A, Chan WC, Greiner TC, Weisenburger DD, Armitage JO, Gascoyne RD, Connors JM, Grogan TM, Braziel R, Fisher RI, Smeland EB, Kvaloy S, Holte H, Delabie J, Simon R, Powell J, Wilson WH, Jaffe ES, Montserrat E, Muller-Hermelink HK, Staudt LM, Campo E, Rosenwald A, Lymphoma/Leukemia Molecular Profiling Project (2005) Diffuse large B-cell lymphoma subgroups have distinct genetic profiles that influence tumor biology and improve geneexpression-based survival prediction. Blood 106(9):3183-3190

6. Aisenberg AC (1993) Primary large-cell lymphoma of the mediastinum. J Clin Oncol 11(12):2291-2294

7. Kolonic SO, Dzebro S, Kusec R, Planinc-Peraica A, Dominis M, Jaksic B (2006) Primary mediastinal large B-cell lymphoma: a single-center study of clinicopathologic characteristics. Int J Hematol 83(4):331-336

8. Savage KJ (2006) Primary mediastinal large B-cell lymphoma. Oncologist 11(5):488-495

9. Zinzani PL, Martelli M, Bendandi M, De Renzo A, Zaccaria A, Pavone E, Bocchia M, Falini B, Gobbi M, Gherlinzoni F, Stefoni V, Tani M, Tura S (2001) Primary mediastinal large B-cell lymphoma with sclerosis: a clinical study of 89 patients treated with MACOP-B chemotherapy and radiation therapy. Haematologica 86 (2):187-191

10. Zinzani PL, Martelli M, Bertini M, Gianni AM, Devizzi L, Federico M, Pangalis G, Michels J, Zucca E, Cantonetti M, Cortelazzo S, Wotherspoon A, Ferreri AJ, Zaja F, Lauria F, De Renzo A, Liberati MA, Falini B, Balzarotti M, Calderoni A, Zaccaria A, Gentilini P, Fattori PP, Pavone E, Angelopoulou MK, Alinari L, Brugiatelli M, Di Renzo N, Bonifazi F, Pileri SA, Cavalli F, International Extranodal Lymphoma Study Group (IELSG) (2002) Induction chemotherapy strategies for primary mediastinal large B-cell lymphoma with sclerosis: a retrospective multinational study on 426 previously untreated patients. Haematologica 87(12):1258-1264

11. Todeschini G, Secchi S, Morra E, Vitolo U, Orlandi E, Pasini F, Gallo E, Ambrosetti A, Tecchio C, Tarella C, Gabbas A, Gallamini A, Gargantini L, Pizzuti M, Fioritoni G, Gottin L, Rossi G, Lazzarino M, Menestrina F, Paulli M, Palestro M, Cabras MG, Di Vito F, Pizzolo G (2004) Primary mediastinal large B-cell lymphoma (PMLBCL): long-term results from a retrospective multicentre Italian experience in 138 patients treated with $\mathrm{CHOP}$ or MACOP-B/VACOP-B. Br J Cancer 90(2):372-376

12. Sekiguchi N, Nishimoto J, Tanimoto K, Kusumoto S, Onishi Y, Watanabe T, Kobayashi Y, Asamura H, Kagami Y, Matsuno Y, Tobinai K (2004) Primary mediastinal large B-cell lymphoma: a single-institution clinical study in Japan. Int J Hematol 79(5):465-471

13. Hamlin PA, Portlock CS, Straus DJ, Noy A, Singer A, Horwitz SM, Oconnor OA, Yahalom J, Zelenetz AD, Moskowitz CH (2005) Primary mediastinal large B-cell lymphoma: optimal therapy and prognostic factor analysis in 141 consecutive patients treated at Memorial Sloan Kettering from 1980 to 1999. Br J Haematol 130(5):691-699

14. Hoelzer D, Ludwig WD, Thiel E, Gassmann W, Loffler H, Fonatsch C, Rieder H, Heil G, Heinze B, Arnold R, Hossfeld D, Buchner T, Koch P, Freund M, Hiddemann W, Maschmeyer G, Heyll A, Aul C, Faak T, Kuse R, Ittel TH, Gramatzki M, Diedrich H, Kolbe K, Fuhr HG, Fischer K, Schadeck-Gressel C, Weiss A, 
Strohscheer I, Metzner B, Fabry U, Gokbuget N, Volkers B, Messerer D, Uberla K (1996) Improved outcome in adult B-cell acute lymphoblastic leukemia. Blood 87(2):495-508

15. Agresti A, Coull BA (1998) Approximate is better than exact for interval estimation of binomial proportions. Am Stat 52:119-126

16. Simon R (1989) Optimal two stage designs for phase II clinical trials. Control Clin Trials 10:1-10

17. Levitt LJ, Aisenberg AC, Harris NL, Linggood RM, Poppema S (1982) Primary non-Hodgkin's lymphoma of the mediastinum. Cancer 50:2486-2492

18. Trump DL, Mann RB (1982) Diffuse large cell and undifferentiated lymphomas with prominent mediastinal involvement. Cancer 50:277-282

19. Barth TF, Leithauser F, Joos S, Bentz M, Moller P (2002) Mediastinal (thymic) large B-cell lymphoma: where do we stand? Lancet Oncol 3(4):229-234

20. Savage KJ, Al-Rajhi N, Voss N, Paltiel C, Klasa R, Gascoyne RD, Connors JM (2006) Favorable outcome of primary mediastinal large B-cell lymphoma in a single institution: the British Columbia experience. Ann Oncol 17(1):123-130

21. Nath SV, Seymour JF (2005) Cure of a patient with profoundly chemotherapy-refractory primary mediastinal large B-cell lymphoma: role of rituximab, high-dose therapy, and allogeneic stem cell transplantation. Leuk Lymphoma 46(7):1075-1079

22. Zinzani PL, Martelli M, Magagnoli M, Pescarmona E, Scaramucci L, Palombi F, Bendandi M, Martelli MP, Ascani S, Orcioni GF, Pileri SA, Mandelli F, Tura S (1999) Treatment and clinical management of primary mediastinal large B-cell lymphoma with sclerosis: MACOP-B regimen and mediastinal radiotherapy monitored by (67)Gallium scan in 50 patients. Blood 94(10):3289-3293

23. Martelli M, Stefoni V, Cabras G, Cortellazzo S, Brusamolino E, Levis A, Botto B, De Vivo A, Natalino F, Erica F, Foa R, Zinzani PL (2006) Rituximab combined with M/VACOP-B and radiotherapy in primary mediastinal large B-cell lymphoma (PMLBCL): a prospective Italian phase II IIL study. Blood 108 (abstract \#4697)

24. Dunleavy K, Pittaluga S, Janik J, Grant N, Steinberg S, Staudt L, Jaffe E, Wilson WH (2005) Primary mediastinal large B-cell lymphoma (PMBL) outcome is significantly improved by the addition of rituximab to dose adjusted (DA)-epoch and overcomes the need for radiation. Blood 106 (abstract \#929)

25. Vassilakopoulos TP, Angelopoulou MK, Galani Z, Sachanas S, Katsigiannis A, Vrakidou E, Poziopoulos C, Constantinou N, Repoussis P, Dimopoulou MN, Kokoris SI, Michali E, Dimitriadou
EM, Siakantaris MP, Kontopidou FN, Kalpadaki C, Viniou NA, Kyriakou E, Korkolopoulou P, Kyrtsonis MC, Panayiotidis P, Roussou P, Pangalis GA (2006) Rituximab-CHOP (R-CHOP) and radiotherapy (RT) for primary mediastinal large B-cell lymphoma (PMLBCL). Blood 108 (abstract \#2745)

26. Muller U, Stahel RA (1993) Gonadal function after MACOP-B or VACOP-B with or without dose intensification and ABMT in young patients with aggressive non-Hodgkin's lymphoma. Ann Oncol 4(5):399-402

27. Armitage JO (2007) How I treat patients with diffuse large B-cell lymphoma. Blood 110(1):29-36

28. Pfreundschuh M, Trumper L, Osterborg A, Pettengell R, Trneny M, Imrie K, Ma D, Gill D, Walewski J, Zinzani PL, Stahel R, Kvaloy S, Shpilberg O, Jaeger U, Hansen M, Lehtinen T, LopezGuillermo A, Corrado C, Scheliga A, Milpied N, Mendila M, Rashford M, Kuhnt E, Loeffler M, MabThera International Trial Group (2006) CHOP-like chemotherapy plus rituximab versus CHOP-like chemotherapy alone in young patients with goodprognosis diffuse large-B-cell lymphoma: a randomised controlled trial by the MabThera International Trial (MInT) Group. Lancet Oncol 7(5):379-391

29. Feugier P, Van Hoof A, Sebban C, Solal-Celigny P, Bouabdallah R, Ferme C, Christian B, Lepage E, Tilly H, Morschhauser F, Gaulard P, Salles G, Bosly A, Gisselbrecht C, Reyes F, Coiffier B (2005) Long-term results of the R-CHOP study in the treatment of elderly patients with diffuse large B-cell lymphoma: a study by the Groupe d'Etude des Lymphomes de l'Adulte. J Clin Oncol 23 (18):4117-4126

30. Feugier P, Virion JM, Tilly H, Haioun C, Marit G, Macro M, Bordessoule D, Recher C, Blanc M, Molina T, Lederlin P, Coiffier B (2004) Incidence and risk factors for central nervous system occurrence in elderly patients with diffuse large-B-cell lymphoma: influence of rituximab. Ann Oncol 15(1):129-133

31. Bishop PC, Wilson WH, Pearson D, Janik J, Jaffe ES, Elwood PC (1999) CNS involvement in primary mediastinal large B-cell lymphoma. J Clin Oncol 17(8):2479-2485

32. Boehme V, Zeynalova S, Kloess M, Loeffler M, Kaiser U, Pfreundschuh M, Schmitz N, German High-Grade Non-Hodgkin's Lymphoma Study Group (DSHNHL) (2007) Incidence and risk factors of central nervous system recurrence in aggressive lymphoma - a survey of 1693 patients treated in protocols of the German High-Grade Non-Hodgkin's Lymphoma Study Group (DSHNHL). Ann Oncol 18(1):149-157 